\title{
Impacts of Ownership Structure on R\&D Investment in GEM companies
}

\author{
Zhang Xinyu ${ }^{1, a^{*}}, \mathrm{Gu}$ Wenlin ${ }^{2, b}$ \\ Address: HOHAI University in Jiangning District,549 mailbox,Nanjing,China \\ E-mail: 690193238@qq.com
}

Keywords: R\&D investment;Growth enterprises market; Ownership concentration; Equity balance degree; Executives shareholding

\begin{abstract}
R\&D is the remarkable feature of the enterprise innovation, it has important significance to promote the construction of national science and technology.Based on growth enterprises market companies'data from 2010 to 2013, this article analyzes the influence between the ownership concentration,equity balance degree as well as executives shareholding and the R\&D input.The empirical results show that the ownership concentration has no significant relationship with R\&D input, the degree of ownership balance and executives shareholding is positively related to the R\&D input,and when executives shareholding reaches a certain proportion, it has more significant influence on R\&D input.
\end{abstract}

\section{Introduction}

In this era of technology economy, technological innovation is an important index to measure a country's comprehensive national strength, the research and development (R\&D) investment is the key factor that promotes technology innovation ability.the statistics bulletin of Chinese science and technology spending in 2012 says that the national research and development spending is 102.94 billion yuan, an increase of $18.5 \%$ over 2011.Research funding input intensity (R\&D/GDP) is $1.98 \%$, 0.14\% more than in 2011.In public companies, $R \& D$, a important guarantee to keep alive in the fierce competition, have a vital role to their growth especially in the growth enterprise market companies.In real environments, there are many factors affect $R \& D$ inputs, including the national macro policy, industry competition, strategic objectives as well as governance structure, the company's internal governance structure is the most influential factor.Based on the gem public enterprises, this paper attempts to research how ownership concentration, ownership balance and executives shareholding impact $R \& D$ input from the perspective of internal governance structure optimization through empirical method, and to provide references for establishing suitable executives shareholding structure which is better for $\mathrm{R} \& \mathrm{D}$ input in the growth enterprise market.

\section{The research hypothesis}

If enterprise's equity concentration degree is high, which means the minority shareholder holds a majority stake, major shareholders will be more actively involved in the company's strategic decision, thus forms powerful supervision on the behavior of the executive.The higher the ownership concentration, the lower the equity liquidity. In this case, major shareholders will pay more attention to the long-term development of the enterprise, thus encourages R\&D investment.Thus, in this study:

H1:The higher the ownership concentration, the higher the R\&D input intensity. 
In practice, there is a conflict of interest between major shareholders and minority shareholders. Because major shareholders have more control over enterprises, they have the residual claims to seek more for their own interests that encroach on the interests of minority shareholders.It makes minority shareholders lose their investment enthusiasm, leading to less effective raising of funds, thus affects the company's normal operation. When a company has several close-stockholding shareholders, there will be mutual supervision and balances between them. The pursuit of private benefit will be restricted, so as to ensure the effective use of operation funds. Thus, in this study:

$\mathrm{H} 2$ : The higher the equity balance degree, the higher the $\mathrm{R} \& \mathrm{D}$ input intensity Shareholders pursuit the maximization of enterprise long-term value, in favor of investment in research and development of new technologies and products. While for managers, maintaining the reputation and chasing personal wealth are more important, and the board of directors usually evaluates the manager's short-term performance, so the manager will give up technology research and development innovation project because of the risk aversion.Executives' equity incentive can effectively solve the contradictions, making them have the double identity of managers and shareholders in order to hold consistent interests with the other shareholders, thus helping to improve the R\&D input.Hence, in this study:

H3:The higher executives shareholding, the higher the R\&D input intensity Exactly how much shareholding ratio have incentive effect to executives?Further study shows that return on net assets of public companies, whose executives shareholding the top 100, is significantly higher than those do not inspire executives, up to $11 \%$ above.It informs that executive incentive policy at this stage has both strong and weak effect, if shareholding ratio is over executive's minimum acceptability, R\&D input will increase significantly.Therefore, we can analogy according to the above conclusion: when executives shareholding is less than $0.1 \%$, the incentive effect is limited, can't irritate the R\&D input; when it reaches or exceeds $0.1 \%$ of the total equity, equity incentive income is enough to make up for the loss of investment that high-risk projects might bring, thus it can promote the R\&D investment.Thus, in this study:

H4: when the executives shareholding exceeds a certain minimum, R\&D investment will be significantly affected.

\section{Variable design and model specification}

\section{Variable design}

(1)The selection of the dependent variable

R\&D input intensity: the foreign and domestic researches often use the proportion of R\&D spending accounting for operating revenue to represent the $R \& D$ input intensity. The more enterprise's operating revenue means the more manageable cash flow, and the R\&D funds are more abundant.So this study also choose this method to measure R\&D input intensity .

(2) The selection of explanatory variables

Ownership concentration: in previous studies, the proportion of the top 10 shareholders or the top 5 shareholders are often selected to measure equity concentration, this study selects the top five shareholders' shareholding to measure it.

Equity balance degree: the ratio of the second to fifth largest shareholders' total shares and the largest shareholder's shares.

Executive shareholding: the ratio of the year-end number of executives shareholding and the total year-end number of equity. 
Whether executives shareholding is reaching $0.1 \%$ :if it is less than $0.1 \%$, the value is 0 ; If it is greater than or equal to $0.1 \%$, the value is 1 .

(3) The selection of control variables

Company size: some scholars put forward that large companies are flush with cash, guaranteeing the process of $R \& D$ activities. While others believe the flexibility of a small company is stronger, so as to promote the innovative activities.In this research, the company scale is expressed by the natural logarithm of year-end total assets.

Profitability: R\&D activities need strong financial security, the better enterprise's profit ability, the more cash flow will be produced, so as to increase R\&D investment.Profitability is represented by the return on total assets in this article.

Asset-liability ratio:R\&D activities may reduce the firm's current profits, leading to a loss of potential capital, so the enterprise cannot guarantee the funds required for R\&D investment timely and adequately.

Model specification. This study constructs the two linear regression models to verify the four assumptions, model design is as follows:

Model1: $\mathrm{RD}=\beta_{0}+\beta_{1} \mathrm{OC}+\beta_{2} \mathrm{~EB}+\beta_{3} \mathrm{ES}+\beta_{4} \mathrm{LEV}+\beta_{5} \mathrm{ROE}+\beta_{6} \mathrm{SIZE}+\varepsilon$

Model2: $R D=\beta_{0}+\beta_{1} \mathrm{OC}+\beta_{2} \mathrm{~EB}+\beta_{3} \mathrm{ES} \mathrm{S}_{01}+\beta_{4} \mathrm{LEV}+\beta_{5} \mathrm{ROE}+\beta_{6} \mathrm{SIZE}+\varepsilon$

\section{Empirical test and result analyses}

Sample selection. This article selects the gem public companies as the research samples from 2010 to 2013, and delete those companies without R\&D investment during the period of 2010-2013 as well as the public companies without disclosure of $R \& D$ input data.In this study, the $R \& D$ investment data, by manual collection and aggregation, mainly come from the "main business situation during the reporting period" in the public companies' annual reports. And other relevant data come from CSMAR database and Shenzhen Stock Exchange.After screening,this study gets 865 effective samples, 2010-2013 effective samples are respectively54, 181, 282, 181.

Descriptive statistics. Status of R\&D input disclosure: more than $90 \%$ of the gem public companies disclose detailed $R \& D$ input in the annual report, and $R \& D$ input intensity ( $R \& D$ input/operating revenue) has been compared with those in the past three years. This shows that the gem public companies in China have paid enough attention to the disclosure of R\&D input data.As shown in Fig.1, the R\&D input intensity maximum is $63.61 \%$, the average is $6.73 \%$. Across the main board and medium and small-sized board public companies in China, the mean of R\&D input intensity is no more than $1 \%$, indicating that $\mathrm{R} \& \mathrm{D}$ receive enough attention in the gem, and achieve the level of developed countries (4\%-7\%).

Ownership concentration: ownership concentration in the gem public company is very high, the maximum of the top five shareholders' shareholding is up to $100 \%$, even the average is $62.96 \%$.Because the gem has ben set up for only 5 years, the main equity is concentrated in the originators.

Equity balance degree: the ratio of the second to fifth largest shareholders' total shares and the largest shareholder's shares is 1.0496 , very close to 1 , indicating that the gem equity balance degree is moderate.

Executives shareholdings: in 865 the gem public company samples, there are 771 companies implement executives shareholding incentives. The average of executives shareholding is $19.70 \%$, the 
standard deviation is $18.92 \%$, the big volatility explains the companies hold different attitudes on executive incentive.

Table 1 Descriptive statistics including all samples

\begin{tabular}{c|c|c|c|c|c}
\hline Variables & Sample & Minium & Maximum & Mean & Standard deviation \\
\hline RD & 865 & 0.0003 & 0.6361 & 0.0673 & 0.0629 \\
\hline OC & 865 & 0.2065 & 1.0000 & 0.6296 & 0.1221 \\
\hline EB & 865 & 0.0104 & 3.8009 & 1.0496 & 0.6208 \\
\hline ES & 865 & 0.0000 & 0.8968 & 0.1970 & 0.1892 \\
\hline
\end{tabular}

As shown in Fig.2, according to whether executives have stakes, the samples are divided in two groups. The R\&D input intensity is $6.9 \%$ on average in companies with executive equity incentives, which is $1.57 \%$ higher than no executives shareholding company.Intuitively, executives equity incentive can promote the company's R\&D investment.

Table $1 \quad$ R\&D input intensity divided by whether executives hold shares

\begin{tabular}{c|c|c|c|c|c|c}
\hline Variable & Groups & Sample & Maximin & Minium & Mean & $\begin{array}{c}\text { Standard } \\
\text { deviation }\end{array}$ \\
\hline RD & $\begin{array}{c}\text { No executives } \\
\text { shareholding }\end{array}$ & 94 & 0.0003 & 0.1978 & 0.0533 & 0.0382 \\
\hline RD & $\begin{array}{c}\text { Executives } \\
\text { shareholding }\end{array}$ & 771 & 0.0016 & 0.6361 & 0.0690 & 0.0651 \\
\hline
\end{tabular}

As shown in table 4 , the average R\&D intensity of 505 public companies, whose executives shareholding greater than or equal to $0.1 \%$, is $7.93 \%$, while the public companies , whose executives shareholding less than $0.1 \%$, is only $0.1 \%$.Intuitively, the public companies whose executives shareholding is more than $0.1 \%$ have bigger R\&D input intensity.

Table 3 Executives shareholding and R\&D input intensify statistics (divided by whether executives shareholding up to $0.1 \%$ )

\begin{tabular}{c|c|c|c|c|c|c}
\hline Variables & Group & Sample & Minium & Maximin & Mean & Standard deviation \\
\hline \multirow{2}{*}{ RD } & $\mathrm{ES} \geq 0.1 \%$ & 505 & 0.0062 & 0.6361 & 0.0793 & 0.0742 \\
\cline { 2 - 7 } & $\mathrm{ES}<0.1 \%$ & 360 & 0.0003 & 0.2743 & 0.0504 & 0.0362 \\
\hline \multirow{2}{*}{ ES } & $\mathrm{ES} \geq 0.1 \%$ & 505 & 0.1000 & 0.8968 & 0.3167 & 0.1621 \\
\cline { 2 - 7 } & $\mathrm{ES}<0.1 \%$ & 360 & 0.0000 & 0.0999 & 0.0291 & 0.0295 \\
\hline
\end{tabular}

The multiple linear regression results. The regression results of model1 shows that $\mathrm{P}$ value of ownership concentration is 0.596 , that means major shareholders' shareholding ratio do not impact on R\&D input. Regression coefficient of equity balance degree is 3.008, T test shows that equity balance degree is at $99 \%$ statistical significant level, proving that medium-sized shareholders can restrict big shareholder, ensure more efficient use of company funds and avoid the risk of major shareholders arbitrage, so as to increase R\&D input. Regression coefficient of executives shareholding is 8.882 , also at $99 \%$ statistical significant level, that means executives shareholding incentive can also promote the R\&D input. 
The regression results obtained from the model 2 demonstrate that in the companies whose executives shareholdings exceeding the minimum proportion $(0.1 \%)$, there is a significant change in R\&D input . When executives share reach $0.1 \%$, the $R \& D$ investment will be significantly promoted, if less than $0.1 \%$, executive incentive effect is not significant.

Table 4 Result of Multiple Linear Regression

\begin{tabular}{c|c|c|c|c|c|c|c|c|c}
\hline Model 1 & $\begin{array}{c}\text { Unstandardized } \\
\text { Coefficients }\end{array}$ & $\mathrm{T}$ & Sig. & VIF & Model 2 & $\begin{array}{c}\text { Unstandardize } \\
\text { d Coefficients }\end{array}$ & $\mathrm{T}$ & Sig. & VIF \\
\hline Constant & -5.902 & -0.786 & 0.432 & & Constant & -2.253 & -0.290 & 0.772 & \\
\hline OC & -0.907 & -0.530 & 0.596 & 1.217 & OC & -0.287 & -0.162 & 0.872 & 1.225 \\
\hline EB & 3.008 & 9.434 & 0.000 & 1.093 & EB & 3.195 & 9.575 & 0.000 & 1.124 \\
\hline ES & 8.882 & 8.511 & 0.000 & 1.088 & ES01 & 1.697 & 4.049 & 0.000 & 1.119 \\
\hline Sig. & $.000^{\mathrm{b}}$ & $\mathrm{R}^{2}$ & 0.218 & & Sig. & $.000^{\mathrm{b}}$ & $\mathrm{R}^{2}$ & 0.168 & \\
\hline D-W & 1.452 & $\mathrm{~F}$ & 41.177 & & D-W & 1.436 & $\mathrm{~F}$ & 30.106 & \\
\hline
\end{tabular}

\section{Conclusion}

The gem public company has high ownership concentration, and the intensity of R\&D investment levels not neat, so there is no correlation between the ownership concentration and the R\&D input. Equity balance degree and is significantly related to R\&D input,indicating that major shareholders also tend to chasing for their own interests just like executives, equity balances can be a very good control of the phenomenon, ensure funds to be serviced in the long-term development of the enterprise.Executives shareholding is positively related to the $R \& D$ input, and when the stake is higher than $0.1 \%$, the stimulation effect of $R \& D$ input is more significant, this shows that executives will abandon short-term profits and seek long-term development until the excitation intensity is strong enough.

In conclusion, reasonable balance between shareholders should be maintained to promote enterprise innovation and increase $R \& D$ investment. Shareholders and managers will reach a consensus in $R \& D$ input if the executives shareholding incentive is over the minimum shareholding level.

\section{References}

[1]Bai Qing\&Luo Shougui .R\&D input and the performance empirical research in two stages[J]. Journal of research and development management, 1(2)pp: 102-110,2014 .

[2] Ren Yuanming. Enterprise R\&D financing constraint and R\&D funds differences in two stages [J]. Science and technology progress and countermeasures,3(2)pp: 92-97,2014.

[3] He Xia \&Su Xiaohua.Executive incentive and enterprise R\&D input, data analysis from new and high technology [J]. Science and technology management research, 6(2) pp: 100-108,2012 .

[4]Zhou Yu\&Xu min. The empirical study of the gem public companies' R\&D input factors [J]. Accounting communication, 12(2) pp: 71-73, 2013.

[5] Ren Haiyun. An empirical study on relationship between equity structure and enterprise R\&D input[J]. Chinese soft science.5(2) pp: 127-135, 2010 .

[6] Li Xiaodi\&Tian Yezhuang, Yao Wei. The impact of multinational corporation R\&D investment on the regional innovation system evolutionary [J]. Soft science .1(2) : 109-114, 2012. 
[7]Zhao Xiang\&Lian, Liu Ding. The comparative study of enterprise R\&D performance ability and the coordinated development [J]. Soft science,9(2)pp: 47-59, 2013.

[8]La Porta R\&Lopez-De-Silanes R, Shleifer A.Corporate Ownership around the World[J].Journal of Finance.54(2)pp:471 - 517,1999.

[9]Vincent L.Barker\&George C.Mueller.CEO Characteristics and Firm R\&D Spending [J].Management Science,6(2),pp:782-801,2002.

[10]Chang-Yang Lee.A Simple Theory and Evidence on the Determinants of Firm R\&D [J].Economics of Innovation \& New Technology.10(2)pp:385-395,2003. 